\title{
Teologie en kenteorie \\ 'n Reaksie op die artikels van Gerrie Snyman'
}

\author{
Wim Vergeer \\ Gereformeerde Kerk \\ Randfontein-Noord \\ RANDFONTEIN
}

\begin{abstract}
Theology and epistemology

A reaction to the articles by Gerrie Snyman'

This study is a reaction to Snyman's critique on the theological activity of the Gereformeerde Kerke of South Africa (GKSA). His critique is firstly examined against the background of a construction of its ow'n paradigm. The identified paradigm is then evaluated as a possible alternative for the theological paradigm of the GKSA. It is conchuded that although the right application of Snyman's critique can help to develop reformed theology, his paradigm is not a tenable alternative for the theological paradigm of the GKSA.
\end{abstract}

\section{Inleiding}

In sy artikels loods Snyman 'n kenteoretiese ondersoek na die teologiebeoefening aan die Teologiese Skool Potchefstroom (TSP). Sy eerste artikel beskryf hy (1992a:251) as "'n eerlike poging om uit te vind hoe die Bybelteks wat as vlas en koring tot die mens kom, uiteindelik deur Gereformeerde teoloe in brood en klere omgesit word". In sy tweede artikel interpreteer hy sekere gebeure in die Gereformeerde Kerke van Suid-Afrika (GKSA) as 'n verandering van geloofwaardigheidstrukture. Snyman (1992b:352) "wil fokus op die konflik wat die verskuiwing van 'plausibility structures' veroorsaak en hoe hierdie konflik hanteer word".

I "Kentcoretiese besinning oor tcologiebooffening aan dic Tcologiese Skool van Potchefstroom dic afgelope twintig jar" (In die Skrıflig. 26 (2) 1992:247-266) en "Binnegevegtc in die GKSA: 'n verskuiwing van 'plausibility' structures'?" (In die Skriflig. 26 (3) 1992 351-367). 


\section{Snyman se kritiek}

Snyman se bevindings verwoord emstige kritiek teen die Gereformeerde 2 teologiese praktyk. Hy meen (1992a:249) dat die teologiebeoefening aan die TSP uit vrees vir humanisme, horisontalisme en sekularisme, die noodsaak van kenteoretiese besinning op die agtergrond dwing. Gevolglik word Platonisme, positivisme en naïewe realisme op ' $n$ onbewuste wyse deel van die Gereformeerde teologiese praktyk. Hierdie onbewuste kenteorie word dan deur die Potchefstroomse teoloë uit die Bybel gepositiveer, en sodoende met daadwerklike openbaringsgesag beklee.

Snyman meen verder (1992b:365) dat nie alle teoloë in die GKSA vir só 'n geloofwaardigheidstruktuur te vinde is nie. As gevolg hiervan sou die GKSA een van sy onstuimigste tye ooit beleef. Daar sou binnegevegte wees tussen sogenaamde modemiste (waagmoedige teoloë) en fundamentaliste (versigtige teoloë). Die moderniste wil deur kritiese realisme die ou teologiese sekerhede vertaal ten einde by nuwe veranderde omstandighede aan te pas. Die fundamentaliste daarteenoor wil met naiewe realisme die Gereformeerde teologie isoleer en insuleer. Hulle wil daarvan ' $n$ ghettoteologie maak om finale waarhede te beskerm.

Op weg na sy bevindinge kom Snyman tot konklusies wat vir elke persoon wat met die Gereformeerde teologie assosieer, ontstellend is:

* Die GKSA het vir baie mense irrelevant begin word (1992a:248; 1992b:363).

* In die refornatoriese teologie heers 'n amper anti-intellektucle denkwyse (1992a:249).

* Deur die verdringing van die kenteoretiese vraagstuk maak die teoloë van die GKSA hulle skuldig aan oewerlose subjektivisme (1992a:258).

- In die teologiebeoefening van die GKSA word die Heilige Gees as 'n soort skuiling teen die rasionele verklaring van die Skrif gebruik (1992a:261).

- Die teologiebeoefening in die GKSA die afgelope 20 jaar skuif die mens opsy (1992a:252) en staan in spanning met die mensbeskouing van Psalm 8 (1992a:265).

- Die Gereformeerde teologiebeoefening maak hom skuldig aan bibliolatrie (1992a:265; 1992b:358).

2 Gereformeerd met $\mathbf{G}$ gespel word in hicrdic artikel deurgaans gebruik met spesificke veruysing na dic teologiebeoefening van die Gereformeerde Kerke in Suid-Afrika, terwyl gereformeerd met 'n g geskryf na die gereformeerde toologie in breër kring verwys. 
* Gereformeerde teoloë wil hulle teologie in segregasie (1992b:359) beoefen en stuur af op 'n sektariese (1992b:363) ghettoteologie (1992b: 359 ).

* In die Gereformeerde teologiebeoefening word individualiteit opgehef, selfkritiek nie toegelaat nie, beperkinge verdoesel en wreed teenoor andersdenkendes opgetree (1992b:360-361).

\section{Strategie}

In 'n sekere sin plaas Snyman se artikels die Gereformeerde teologie in 'n knyptang. Word die artikels geïgnoreer, bevestig dit juis sy aanspraak dat die Gereformeerde teologie die kenteoretiese gesprek op die agtergrond dwing. Word daar heftig en apologeties daarop gereageer, dan staan die sogenaamde positivistiese probleemloosheid van die Gereformeerde benadering weer op die voorgrond.

Snyman stel self ' $n$ reaksie voor. Hy doen in sy eerste artikel (1992a:250) ' $n$ beroep op Gereformeerde teoloë om hulle kenteoretiese vertrekpunte te verdiskonteer. Hy doen aan die hand dat elkeen sy raamwerk op die tafel plaas om verskille beter te kan hanteer en die bitterheid uit debatte te neem. Hierdie voorstel is egter te idealisties. Dit impliseer byvoorbeeld ten minste ' $n$ mate van eenstemmigheid oor die definisie van kenteorie, en die plek en belang daarvan in die teologie. ${ }^{3}$ Sodanige eenstemmigheid moet in die Suid-Afrikaanse teologie nog gevind word.

In hierdie artikel word 'n ander weg voorgestel - 'n weg gemik op groter wedersydse begrip. Dit wil soveel as moontlik vanuit Snyman se eie standpunt sy artikels probeer verstaan (punt 4 ), die kritiek oorweeg (punt 5), en dan 'n reaksie voorstel (punt 6).

\section{Die verstaan van Snyman se artikels}

Geen artikel ontstaan ooit in ' $n$ akademiese lugleegte nie. ${ }^{4}$ Ook die artikels van Snyman kom uit 'n bepaalde paradigma, en funksioneer binne die konteks van 'n spesifieke fase van die ontwikkeling van die Suid-Afrikaanse teologie. Behoor-

3 Sonder hicrdic censtemmigheid kom dic moontlikheid om mekaar hoegenaamd te verstaan in gedrang (Gecrtsema. 1969:40)

4 Hicroor het Thomas Kuhn (1970) ortuigend geskryf. Sy standpunte oor die aard van wetenskaplike ontwikkeling is ondertussen ook in dic Suid-Afrikaanse toologie wyd besproek en aanvaar. veral sodert die 1988 RGN-kongres oor "Paradigms and progress in theology" (Mouton. et al., 1988) 
like verdiskontering van Snyman se artikels impliseer dus paradigmatiese plasing (hoe voorlopig dan ook).

\subsection{Snyman se paradigma}

'n Handige 'sleutel' vir die konstruering van Snyman se waarskynlike paradigma is Lategan (1984:1-17) se oorsig van die hedendaagse teologiese hermeneutiek. Vir Lategan (1984:14) is die uiteindelike doel van die hermeneutiek kreatiewe interpretasie. In hierdie proses speel kommunikasiegebeure vir hom 'n belangrike rol (1984:1-4). Hy onderskei drie basiese elemente in hierdie kommunikasiegebeure, naamlik bron (source), boodskap (message/text) en leser (receptor). Sy navorsing toon aan dat elkeen van hierdie elemente opeenvolgend prominensie geniet het, en dat daar deesdae op die laaste element (receptor/ kreatiewe leser) gefokus word.

Sowel Lategan (1984:4) as Snyman (1992a:263) meen dat die fokus op die kreatiewe leser onvermydelik lei tot belangstelling in die kenteoretiese nadenke en sosiologiese konteks van die leser. Dat die fokus op die kreatiewe leser waarskynlik in breë trekke die paradigma vir Snyman se kommentaar op die GKSA se teologiebeoefening vorm, kan afgelei word uit onder andere die volgende:

* Sy belangstelling in ' $n$ kenteoretiese besinning oor teologiebeoefening aan die TSP.

* Sy fokus op net die laaste 20 jaar van teologiebeoefening aan die TSP.

* Sy aandrang op die erkenning van die kreatiwiteit van die mens as skeppende leser (1992a:247, 248, 264, 265; 1992b:358).

* Sy interpretasie van die binnegevegte in die GKSA - hoofsaaklik vanuit sosiologiese ondertone (1992b:351, 353, 364, 365).

Snyman se paradigma word dus voorlopig geïdentifiseer as die 'nuwere' teologiese hermeneutiek. ${ }^{5}$

\subsection{Snyman se paradigma en die paradigma van die GKSA}

Hoe staan die Gereformeerde teologie ten opsigte van Snyman se voorlopig geidentifiseerde paradigma?

5 Met 'nuwere' teologiese hermencutick word vir die doclcindes van hierdie artikel, daardic hermeneutick aangedui wat die $\mathrm{klcm}$ op kommunikasicgebcure laat val. wat kreatiewe interpretasie as docl het en wat fokus op die rol van die kenteorie en sosiologie van dic kreaticuc leser 
Alhoewel die Gereformeerde teologie sekerlik nie die fokusse en ontwikkelings van die hedendaagse hermeneutiek vrygespring het nie, en verdienstelike pogings al aangewend is om te bewys dat die moderne metodes van verklaring van die Nuwe Testament nie noodwendig in stryd met die Gereformeerde Skrifbeskouing en die belydenisskrifte is nie (vgl. Botha, 1986:259-283 en Janse van Rensburg, 1991:531-551), is dit duidelik dat dit in wese negatief daarteenoor staan. ${ }^{6}$

Hierdie negatiewe houding word ook gereflekteer in die kritiek wat die Gereformeerde teoloë in elkeen van die fases wat deur Lategan onderskei word, moes verduur:

* Tydens die eerste (historiese) fase is hulle van vermyding van die historiese kader beskuldig (Deist, 1984:49).

* Tydens die tweede (strukturalistiese) fase is hulle beskuldig van bloot lippediens aan die moderne linguistiek (Thom, 1983:1-4).

* In die derde (reseptor) fase word hulle beskuldig van opsyskuiwing van die mens (Snyman, 1992a:252).

Uit die kontinuiteit van bostaande kritiek kan afgelei word dat dit om meer as ' $\mathrm{n}$ blote opsyskuiwing, onderdrukking of onderwaardering van 'n bepaalde aspek (Snyman, 1992a:252, 257, 258) van die hedendaagse hermeneutiek gaan. Dit is meer waarskynlik dat twee verskillende beskouings oor wat hermeneutiek is, hieraan ten grondslag lê.

\subsection{Twee teologiese paradigmas}

Die feit van twee teologiese paradignas wat teenoor mekaar staan, moet in kritiek en die oorweging van kritiek verdiskonteer word. Eers dan is die verwagting van wedersydse begrip realisties.

In sy artikels hou Snyman waarskynlik nie genoeg rekening hiermee nie. Dit lei onder andere tot

* sy, vanuit eie paradigma gemotiveerde konklusie dat die GKSA nog in die tweede (strukturalistiese) fase van die ontwikkeling van die hedendaagse herneneutiek staan (Snyman, 1992a:263), ${ }^{7}$

6 Bydracs/standpunte uit Gereformecrde hock was op hierdic terrein in dic algemeen reaktief, krities en apologeties van van aard (bv. Van Wỵk, 1983, 1985, Floor, 1979; Coetzee, J.C. 1979; Coctzec, C. F C. 1988; Lion-Cachet. 1984, 1985).

7 En dit terwyl dic tooloe van die GKSA ocnskınlik van meet af aan nie deel wil hê aan 'n hermeneutick met kreatiese interpretasie as uitcindelike docl nic. 
* $\quad$ sy voorstelling dat dit net die TSP is wat die hoofstroom van die Suid-Afrikaanse teologie verlaat het om 'n irrelevante ghettoteologie te bedryf (Snyman, 1992b:361,362), 8

* sy verskraalde studieveld, waarin hy net twintig jaar van die Gereformeerde teologiese paradigma in oënskou neem (Snyman, 1992a:247) ${ }^{9}$ en

* sy eensydige sosiologiese beoordeling van meningsverskille en misverstande in die Gereformeerde teologie as onversoenbare binnegevegle wat op faksievorming afstuur (Snyman, 1992b:351-353)10.

Die grootste beswaar teen Snyman se kritiek is waarskynlik in bogenoemde leemtes geleë. Sy transendente beoordeling en veroordeling vanuit eie paradigma, sonder blyke van sensitiwiteit vir die immanente waardes van die Gereformeerde paradigma, kompliseer konstruktiewe gesprekvoering.

\section{Die oorweging van Snyman se artikels}

Die feit dat Snyman die Gereformeerde teologie vanuit die paradigma van die 'nuwere' hermeneutiek lees en beoordeel, relativeer nie alleen die waarde van sy kritiek nie ('n skewe beeld van die teologiebeoefening aan die TSP is op hierdie manier onvermydelik), maar maak dit ook moeilik om dit sinvol te oorweeg.

Daarom word in hierdie artikel nie probeer om sy skerp kritiese uitsprake punt vir punt te probeer weerlê nie." Daar word eerder 'n poging aangewend om vas te stel wat die essensie van sy kritiek is, en dan daarop te reageer.

8 Uit literatuur (Deist, 1986:1-5; 1991-367-385) wil dit tog voorkom of dic paradigma waarbinne die teologicbcocfening an dic TSP plaasvind, nie net tot dic GKSA beperk is nic, maar ook redelik algemene aanhang in dic Nederduitse Gereformecrde Kerk en die Nederduitsch Hervormde Kerk genict

9 Van Huyssteen (1983:198) stel tereg dat dic herkoms van teologiese denkmodelle alleen bepaal kan word as dic groep wat in elk geval ter sprake is, bestudecr kon word Dic groep wat relevant is vir dic bestudering van dic Gereformeerde paradigma strek oor meer as twintig jaar Ook dic invloed van Potchefstroomse filosowe cn ander vakwetenskaplikes op die Gereformeerde teologicse paradigma moet verken word.

10 'n Meer objektiewe sosiologiese ondersock sou waarskynlik bevind dat daar veel meer is waaroor sogenaamde versigtiges en waagmoediges dit eens is, as waaroor hulle verskil

11 Sodanige apologetiese benadering sou teenproduktief wees. Dic merietc en grondslag van die Gereformeerde teologie is sodanig dat 'n erlike tetiese uiteensetting en oorweging 'n beter en meer opbouende woerlegging bevat. 


\subsection{Die essensie van Snyman se kritiek}

Op die oog af lyk dit of Snyman (1992a:250, 265) die Gereformeerde teoloë bloot uitnooi om hulle denkraamwerk op die tafel te plaas en kenteoretiese ontkenning af te lê. Daar is egter 'n verskuilde agenda, want later (1992b:365) word dit duidelik dat hy die GKSA tot die krities realistiese manier van teologiebeoefening probeer oorhaal.

Die essensie van sy kritiek kan dus geidentifiseer word as paradigma-kritiek.

Met sy kritiese realisme staan Snyman in die voetspore van die krities realistiese rasionaliteitsmodel wat Van Huyssteen (1987:169 e.v.) ontwerp het. Die oorweging van Snyman se artikels beteken dus in wese die oorweging van die krities rasionele teologiebeoefening in teenstelling tot die Gereformeerde teologiebeoefening. Dit word vervolgens gedoen, eerstens ten opsigte van oorsprong en tweedens ten opsigte van praktyk.

\subsection{Die oorweging van die Kritiese Rasionalisme (oorsprong)}

\subsubsection{Oorsprong}

Die krities rasionele denkhouding in die Suid-Afrikaanse teologie het 'n Europese oorsprong.

Beskuldigings van onder andere Bartley (1964) en Albert (1968) dat teoloë hulle in wetenskapsbeoefening skuldig maak aan 'n irrasionele vlug na geloofsbetrokkenheid en hulle immuniseer ten opsigte van die eise van die wetenskap, het gelei tot pogings van teoloë soos G. Sauter (1975), W. Pannenberg (1973) en H. Hempelmann (1980) om die redes vir hulle geloofsbindinge en denkmodelle wetenskaplik uiteen te sit.

Die Suid-Afrikaanse teoloog W. van Huyssteen (wat in Duitsland studeer het) aanvaar self ook die uitdaging van die Kritiese Rasionalisme. Hy kritiseer die ontwerpe van Sauter (1987:125-150), Pannenberg (1987:95-124) en Hempelmann $(1983: 197,198)$ en ontwerp sy eie bekende Teologie as kritiese geloofsverantwoording.

In Suid-Afrika is die aktualiteit van die probleemstelling van Bartley en Albert grootliks bevorder deur die RGN-studies in navorsingsmetodologie. Van Huyssteen se Teologie as kritiese geloofsverantwoording is as tweede nommer van hierdie studies gepubliseer. Vervolgens is ' $n$ konferensie met as oorkoepelende tema: "Paradigms and progress in theology" in 1988 deur die RGN geïnisieer. 
Mouton et al. (1988:3) sien die volgende publikasies as aanleidende oorsake vir die hou van hierdie spesifieke konferensie:

* Thomas Kuhn se The Structure of Scientific Revolutions.

* Van Huyssteen se Teologie as kritiese geloofsverantwoording.

'n Verdere rede wat genoem word vir die besinning op hierdie konferensie, is die verwagting dat ' $n$ nuwe paradigma besig is om op die toneel van die Suid-Afrikaanse teologie te verskyn (Mouton, et al., 1988:3).

Die referate wat tydens hierdie kongres gelewer is, is as vyfde nommer van die RGN-studies in Navorsingsmetodologie gepubliseer. Op hierdie manier is die krities rasionele denkhouding waarskynlik in die Suid-Afrikaanse teologie gepopulariseer.

\subsubsection{Oorweging}

Wanneer ' $n$ bepaalde probleemstelling uit sy Europese konteks geïsoleer word, en op 'n eenvoudige wyse in 'n ander (Suid-Afrikaanse) konteks 'oorgeplant' word, kan daar verskeie gevaarlike leemtes ontstaan. 12

\subsubsection{Antropologiese en ontologiese ontworteling}

Saam met die eenvoudige 'oorplanting' van Europese probleemstellings, word onbewustelik ook die ontologiese en antropologiese agtergronde daarvan oorgeplant. Hierdie agtergronde word meestal nie blootgelê en beoordeel nie, en baie onbeantwoorde vrae kom hierdeur na vore.

Is dit byvoorbeeld al uitgemaak van watter ontologie die Kritiese Rasionalisme uitgaan? Watter antropologiese basis is daar vir die kenteoretiese pre-okkupasie van die Kritiese Rasionalisme? Watter definisie van teologie word in die Kritiese Rasionalisme gehanteer?

\subsubsection{Eensydigheid}

'n Probleemstelling kan ook eensydig oorgeplant word. Positiewe of negatiewe debatte wat in Europa rondom 'n bepaalde probleemstelling plaasgevind het, bly dikwels onbekend in Suid-Afrika.

12 Besware teen hierdie praktyk is reeds in 1979 deur onder andere Floor geopper (vgl. Floor, 1979:12) 


\subsubsection{Konteksvervreemding}

Die Europese teologiese konteks verskil van die Suid-Afrikaanse teologiese konteks. Was vrae na kenteoretiese vooronderstellings, die aard van kommunikasie en die rol van die kreatiewe leser inderdaad die afgelope paar jaar die dringendste vrae in die Suid-Afrikaanse teologiese konteks? Of was die aanvaarding van hierdie Europese probleemstellings deel van 'n onbewuste konteks-ontvlugting?

Daar is in die Gereformeerde teologiese praktyk ervaar dat hierdie agtergronde en eensydige en konteksvreemde probleemstellings dikwels in konflik kom met die spesifiek Gereformeerde verstaan van die Skrif en belydenis.

'n Goeie voorbeeld hiervan is Snyman se verheerliking van die "kreatiewe vermoëns' van die mens. Dit sou moontlik wees om in Snyman se eie styl (1992a: 252-257) hierdie begrip via die Humanisme terug te voer na die optimistiese mensbeeld van die Grieke. 'n 'Verskuilde' Platonistiese motief sou dus óók in die antropologie van Snyman blootgelê kon word. Hierdie motief speel in sy (1992a: 247,248 ) eksegese van Psalm 8 ' $n$ rol, word sodoende met openbaringsgesag beklee en in sy kenteorie gepositiveer.

Hierdie antropologiese vertrekpunt (wat Snyman waarskynlik van die Kritiese Rasionalisme oorneem), bring hom oënskynlik in konflik met die Gereformeerde belydenis van die mens se natuurlike verdorwenheid en onbekwaamheid tot enige goed (Heidelbergse Kategismus, vr. 8 en Dordtse Leerreëls, hfst. 3, 4).

Dit kom voor of Snyman hierdie konflik wil vermy. Aan die een kant gebruik hy juis die leer van die natuurlike verdorwenheid van die mens as ' $n$ oortuigende argument om die noodsaak van kontroleerbare modelle aan te toon (1992a:264). Aan die ander kant trek hy hierdie leer egter nie tot in sy volle konsekwensies deur nie. Die teologiese en wetenskaplike belang van wedergeboorte en die leiding van die Heilige Gees word deur Hom geïgnoreer. In die plek daarvan gryp hy na 'n soort kreatiwiteit wat (behalwe dat dit nou gepaard gaan met moeite) klaarblyklik nie deur die sondeval beinvloed is nie (1992a:264).

Die indruk word hier gewek dat moeitevolle kreatiwiteit en kontroleerbare modelle die plek van wedergeboorte en die Heilige Gees kan inneem.

Wanneer teoloë kenteoretiese vertrekpunte aanvaar waarin die mens se 'natuurlike onbekwaamheid tot enige goed' prysgegee word, en die rol van wedergeboorte en die leiding van die Heilige Gees nie verdiskonteer word nie, moet hulle verwag dat daar vanuit Gereformeerde (en waarskynlik selfs gereformeerde) hoek hieroor ernstige beswaar sal kom, en dat teorieè, kritiek en voorstelle wat op só ' $n$ vertrekpunt bou, met agterdog bejeên sal word. 


\subsection{Die oorweging van die Kritiese Rasionalisme (praktyk)}

Die gevaar van beoordeling van een paradigma uit die oogpunt van ' $n$ ander paradigma word deur Snyman se benadering geillustreer. Wie sal die skeidsregter tussen twee verskillende paradigmas wees? Die lyk die beste om 'n paradigma aan sy eie maatstawwe te meet.

Die drie minimumvereistes wat Van Huyssteen $(1983: 204,203)$ vir 'n geloofwaardige teologiese rasionaliteitsmodel stel, kan waarskynlik sonder vrees vir teëspraak as maatstaf vir Snyman se teologiese paradigma aangewend word. Hierdie minimumvereistes is:

* Die werklikheidsbetrokkenheid van teologiese uitsprake en teorieë.

* Die kritiese en probleemoplossende vermoè van teologiese uitsprake en teorieè.

* Die ontwerpende en progressiewe aard van teologiese uitsprake en teorieë.

Hoe vaar die teologiese paradigma van die 'nuwere' hermeneutiek as dit aan hierdie minimumvereistes gemeet word?

\subsubsection{Werklikheidsbetrokkenheid}

Van Huyssteen $(1987: 173,177)$ onderskei tussen werklikheidsbetrokkenheid as kognitiwiteit en werklikheidsbetrokkenheid as kontekstualiteit.

\subsubsection{Werklikheidsbetrokkenheid as kognitiwiteit}

Met werklikheidsbetrokkenheid as kognitiwiteit bedoel Van Huyssteen (1987: $173,174)$ die werklikheid van God. Die enigste geldige weg na die werklikheid van God is vir hom ons geloofstaal. Hierdie geloofstaal is relasioneel van aard. Van Huyssteen (1987:174) beweer dat die relasionaliteit van geloofstaal ten diepste geïnteresseerd is in objektiewe gehalte.

Hierdie strewe na die objektiewe deur middel van intersubjektiwiteit, kom egter nie los van relativisme nie. Selfs vanuit die Historiese Kritiek kom daar beswaar hierteen. Van Aarde $(1988: 58,59)$ byvoorbeeld, verwys na hierdie relativisme as ' $n$ deel van ' $n$ beweging na holisme en panteisme, en beskou dit tereg as teologiese selfmoord. 


\subsubsection{Werklikheidsbetrokkenheid as kontekstualiteit}

Van Huyssteen (1987:177) onderskei drie kontekste vir die werklikheidsbetrokkenheid van teologiese uitsprake: godsdienshelewing, die kerk en teologiese refleksie.

Juis as gevolg van die relativering van teologiese uitsprake, het die 'nuwere' hermeneutiek egter sy vermoë om gesagvol in 'n konteks betrokke te raak, geminimaliseer. Dit het om akademiese en wetenskaplike redes feitlik onmoontlik geword om in 'n sekere konteks te sê: so sê die Here.

Die Kritiese Rasionalisme het die teologie grootliks verintellektualiseer, en dit sodoende juis vervreem van die konteks wat aan alle teologisering voorafgaan, naamlik die konteks van alledaagse godsdiensbelewing (vgl. Van Huyssteen, 1987:179).

Hierdie verintellektualisering word nie alleen sigbaar in die relativering van teologiese uitsprake nie, maar ook in vakwetenskaplike versplintering: Kleinforschung tot in die fynste besonderhede het die gehoor wat sinvol oor 'n bepaalde teorie kon meepraat, in die meeste gevalle tot 'n paar individue beperk.

'n Gewone predikant, met al sy bedieningsverpligtinge moes nou ook filosoof, metodoloog, linguis en sosioloog wees, net om die ingewikkelde modelle wat op die Skrif toegepas word te verstaan. Min het hiervoor kans gesien.

Dit sou beweer kon word dat die Kritiese Rasionalisme van die teologie ' $n$ ondiensbare wetenskap vir 'n elitistiese groep spesialiste gemaak het. Wanneer 'n opname gemaak sou word oor die werklikheidsbetrokkenheid van die bydraes van byvoorbeeld die NTWSA die afgelope vyf jaar, sou die beskuldiging van isolasie en ghetloteologie (Snyman, 1992b:361 e.v.) waarskynlik omgekeer kon word.

\subsubsection{Kritiese en probleemoplossende vermoë}

Volgens Van Huyssteen (1987:192) is daar drie kriteria vir die probleemoplossende vermoë van 'n teologiese teorie of model: die Bybel, die iradisie van teologiese refleksie (o.a. belydenis) en die konteks van kontemporêre denke.

Die teoloë van die 'nuwere' hermeneutiek sal egter die eerste wees om te erken dat hulle nie almal hierdie drie kriteria aanvaar nie, en dat daar onder diegene wat dit aanvaar, uiteenlopende verskille is oor die definisie, rol en gesag van hierdie kriteria in die toetsing van teologiese teorieê of modelle. 
'n Babelse verwarring heers gevolglik oor die normatiewe waarde van wetenskaplike bydraes op teologiese gebied, en die etiese verantwoordelikheid van die teoloog ten opsigte van sy bevindinge. Die indruk ontstaan dat enige model maar op die Skrif toegepas kan word, solank dit net kenteoreties verantwoord word.

\subsubsection{Ontwerpende en progressiewe aard}

As kriteria vir die ontwerpende en progressiewe aard van 'n teologiese paradigma geld vir Van Huyssteen (1983:205) "wanneer hulle vorder deur probleme op te los".

Die vraag kan gevra word of die krities rasionele paradigma van die 'nuwere' hermeneutiek nie eerder probleemskeppend as probleemoplossend op die SuidAfrikaanse teologiese gemeenskap ingewerk het nie. Meningsverskil bestaan ook oor wanneer 'n teologiese model werklik progressief van aard is (Van Aarde, 1988:59). Vir die 'nuwere' hermeneutiek sou progressie waarskynlik 'rasionalisering' en 'verwetenskapliking' van teologiese uitsprake beteken. Vir Snyman gaan dit waarskynlik om die ontplooiing van die kreatiewe vermoëns van die mens in sy teologiese besig-wees.

Is alle teologiese kreatiwiteit noodwendig progressief? Het die uitbreiding van die Koninkryk van God nog 'n plek in die 'nuwere' hermeneutiek se beskouing oor wat 'progressief' in die teologie is, of gaan dit om kreatiwiteit ter wille van kreatiwiteit?

\subsection{Gevolgtrekking}

Uit bostaande word die gevolgtrekking gernak dat die paradigma van die 'nuwere' hermeneutiek in sowel oorsprong as praktyk vir 'n Suid-Afrikaanse teoloog ondiensbaar is. Dit stel konteksvreemde probleme en misluk volgens eie maatstawwe in baie opsigte.

\section{6. 'n Reaksie op Snyman se artikels}

Hoe moet daar dan op Snyman se artikels gereageer word? Hierdie artikel wil aan die hand doen dat Gereformeerde teoloë aan die kenteoretiese debat begin deelneem - vanuit 'n eie paradigma het hulle 'n besondere bydrae om te lewer.

Bogenoemde voorstel sal egter in die Gereformeerde teologiese praktyk verskeie struikelblokke moet oorkom:

* Hierdie deelname is 'n taak vir die Gereformeerde teologiese gemeenskap, wat hieroor konsensus moet bereik. 
* Moeite sal gedoen moet word om te omskryf presies wat die Gereformeerde paradigma behels.

* In die Gereformeerde Teologie was daar tot onlangs "weinig aptyt" vir sodanige gesprek (Lion-Cachet, 1985:45-48). Dit sal eers gekweek moet word, byvoorbeeld deur aan te toon dat so ' $n$ deelname vanuit 'n eie paradigma nie noodwendig deel vorm van die 'nuwere' en subjektivistiese benadering tot die hermeneutiek nie, maar eerder deel vorm van die erkenning van die sondige gebrokenheid van die teoloog as wetenskaplike.

* Kennis sal geneem moet word van die baie belangrike werk wat reeds gedoen is ten opsigte van die definiëring van 'n Gerefonneerde ontologie, antropologie en kenteorie. ${ }^{13}$

Voorgestelde deelname aan die kenteoretiese debat is ook 'n goeie kommunikasiestrategie. So 'n strategie het nodig geword omdat daar in sekere kringe ervaar word dat die "stem van Potchefstroom stil geword het" (Snyman, 1991). Hierdie ervaarde 'stilte' word deur aanhangers van die 'nuwere' hermeneutiek geïnterpreteer as ' $n$ bewys vir fundamentalisme, ' $n$ anti-intellektuele denkwyse, ' $n$ immuniseringstaktiek, positivisme, en het 'n kapstok geword vir baie ander negatiewe etikette (Snyman, 1992; Deist, 1984; Van Huyssteen, 1988).

Indien Gereformeerde teologie egter ooit 'n sogenaamde fundamentalistiese en positivistiese ghetto-teologie word, sal dit waarskynlik eerder toe te skryf wees aan ' $n$ verkeerde reaksie op die kritiek van die 'nuwere' hermeneutiek as aan 'n innerlike oortuiging. Die ervaring dat die "stem van Potchefstroom" ook in die teologie stil word, moet eerder toegeskryf word aan die feit dat Potchefstroom nie meer slaag om met 'n sekere deel van die Suid-Afrikaanse teologiese gemeenskap te kommunikeer nie, as dat daar om fundamentalistiese redes nie meer vanuit Potchefstroom gepraat word nie. ${ }^{14}$

Sonder om in kenteoretiese pre-okkupasie te verval, kan die Gereformeerde teoloog vanuit 'n eie paradigma waarskynlik beter as die 'nuwere' hermeneutiek aan die kriteria van wetenskaplikheid wat deur die Kritiese Rasionalisme gestel word, beantwoord. 'n Baie voorlopige en individuele poging om iets hiervan aan te toon, en om in die proses ook 'n paar moontlike Gereformeerde kenteoretiese ver-

13 Bywoorbecld deur Dooycweerd. Vollenhoven en ook Potchefstroomse filosowe soos Stoker, Taljaard en Van der Walt.

14 Potchefstroomse teoloc is op 'n verskeidenheid van teologiese vakgebıede merkwaardig produktief en lewer nasionaal en internasionaal gewaardeerde bydraes 
trekpunte vir die aanhangers van die 'nuwere' hermeneutiek verstaanbaar te definieer, volg hieronder. ${ }^{15}$

\subsection{Werklikheidsbetrokkenheid}

Die Gereformeerde teologie wil ook werklikheidsbetrokke wees. Van Wyk (1983:217) bevestig dat 'n teologie wat nie werklikheidsbetrokke is nie, geen teologie genoem kan word nie. Die werklikheid van God en konteks speel ook in die Gereformeerde teologie ' $n$ onmisbare rol.

In die Gereformeerde teologie staan een werklikheid egter uit as nonnatief en preskriptief ten opsigte van die ander werklikhede. Hierdie werklikheid is die werklikheid van God in Jesus Christus (Kol. 2:17).

Die Kritiese Rasionalisme erken ook die werklikheid van God, maar dan as kognitiwiteit (Van Huyssteen, 1983:173, 174). Ten diepste gaan die Kritiese Rasionalisme dus waarskynlik uit van die bestaan van die denkende leoloog as finale werklikheid (cogito ergo sum). Hierteenoor wil die Gereforneerde teologie uitgaan van die werklikheid van God as finale werklikheid. Hierdie werklikheid is die objektiewe, ontiese en tegelyk onbewysbare werklikheid wat aan alle ander werklikhede voorafgaan, en waaruit alle ander werklikhede (ook die werklikheid van 'n teoloog wat in 'n bepaalde konteks wetenskaplik besig wil wees) voortkom en bepaal word. Hy was altyd, is reeds, en moet ook nog kom (Op. 1:4).

Die aanvaarding van hierdie vertrekpunt het belangrike implikasies vir die teologie. In die Gereformeerde teologie word die werklikheid nie net gesien as 'n studie-objek waarop die teoloog met sy wetenskaplike denkaktiwiteit beslag lê nie. Daar word uitgegaan van die vooronderstelling dat die werklikheid van God in Jesus Christus beslag lê op die teoloog! Die werklikheid van Jesus Christus wil beslag lê op die hele teoloog in al sy handelinge, van sy voorwetenskaplike vooronderstellings tot sy wetenskaplike teorieè en konklusies. Hierdie beslaglegging is ook deel van die taak van die teoloog, naamlik om elke gedagte in elke konteks vir die werklikheid van Jesus Christus gevange te neem (2 Kor. 10:5).

Die beslaglegging geskied deur openbaring (die Bybel) en begeleidende inwoning (die Heilige Gees) van God. Vanuit die gesigspunt van die werklikheid van God in Jesus Christus, is hierdie beslaglegging inderdaad probleemlose en volkome deursigtige objektiewe kommunikasie en bemoeienis.

15 Die Kritiese Rasionalisme (Van Huyssteen) se kriteria vir wetenskaplikheid word ter wille van dic voortgang van die debat as raamwerk gevolg. Dit sal egter durdelik word dat daar vanuit 'n cie paradigma 'n cie interpretasic aan hicrdic kriteria gegec word 
Daar is egter ook ' $n$ ander werklikheid wat die teologie as wetenskap beïnvloed: die werklikheid van 'n gebroke, sondige en vervloekte skepping, waarvan die teoloog as mens deel is. Die Gereformeerde teoloog sien homself dus as ' $n$ sondaarmens, van nature geneig om verkeerd te verstaan en ongehoorsaam te wees. Anders as wat Snyman beweer (1992a:264), beïnvloed die sonde ook die teoloog se kreatiwiteit. Van nature is ook sy kreatiewe vermoëns eerder op regressie as op progressie gerig.

Tussen genoemde twee werklikhede bestaan daar konflik: dit kan beskryf word as die konflik tussen waarheid en leuen. Snyman (1992a:252,256) interpreteer die erkenning van hierdie konflik as Neo-Platonisme. Hierdie interpretasie hou egter in die lig van die oplossing van die konflik nie stand nie

Die oplossing van die konflik is geleë in die genade van God. Hy maak die oorwinning oor die leuen moontlik deur sy Seun as offer te gee. Sy offer vorm 'n basis-vooronderstelling vir alle Gereformeerde teologie. Sonder hierdie offer is geen suiwere kennis van God moontlik nie. Slegs deur sy bemiddeling word die waarheid geopenbaar en is dit kenbaar. Hierdie waarheid bestaan nie net uit feite nie, maar word in 'n persoonlike en gehoorsame geloofsverhouding geken.

Met hierdie uitgangspunt word nie die sogenaamde 'relasionele' waarheidsbeskouing aanvaar nie. In die relasionele waarheidsbeskouing kom die waarheid in verhouding tot stand. ${ }^{16}$ Vir die Gerefonneerde teologie bestaan die waarheid objektief, onafhanklik van die subjek in die werklikheid van Christus. Die waarheid kan egter slegs in 'n persoonlike en gelowig-gehoorsame verhouding met Christus geken word. Vanweë die sondige gebrokenheid van die mens bly hierdie ken altyd ten dele en is dit nooit volkome nie.

Die Gereformeerde teologie wil dus in 'n sekere opsig meer as werklikheidshetrokke wees. Die Gerefonmeerde teologie wil deur die werklikheid van God in Jesus Christus gevange wees. Die Gerefonneerde teoloog wil ook werklikheidsoorwinnend wees deur in elke sondige en gebroke konteks (godsdiensbelewing, kerk, teologiese refleksie [Van Huyssteen, 1987:177-186]) die waarheid van die werklikheid van Jesus Christus vir daardie konteks te probeer konkretiseer.

\subsection{Kritiese en probleemoplossende vermoë}

Snyman (1992a:251) wil weet hoe die Bybelteks wat as vlas en koring tot die mens kom. uiteindelik deur (iereformeerde teoloë in brood en klere omgesit word. Agter hierdie vraag kan 'n onaanvaarbare vooronderstelling skuil; naamlik dat die Bybel eers 'voedingswaarde' het as dit deur teoloë verwerk word. Ter 
wille van die voortgang van die debat word daar egter op sy metafoor voortgeborduur.

Dat vlas en koring in die teologie inderdaad brood en klere kan word, dra 'n wonderkarakter wat in die 'nuwere' hermeneutiek uit die oog verloor word. Die 'nuwere' hermeneutiek staan agressief teenoor daardie wonder, en wil dit ten alle koste sy wonderkarakter ontneem deur alles, selfs vooronderstellings te verwetenskaplik. ${ }^{17}$

Die aard van hierdie wonder kan as Godsbemoeienis gedefinieer word. Die Gereformeerde teoloog wil hom aan hierdie wonder uitlewer, en daaraan diensbaar stel.

Die feit dat vlas en koring in die teologie brood en klere kan word, staan in die Gereformeerde teologie in dieselfde onverstaanbare en wonderbare karakter as dit wat elke Goddelike bemoeienis met die mens kenmerk: Alhoewel God 100\% in beheer is, bly die mens ook $100 \%$ verantwoordelik. Hierdie onverstaanbare en wonderbare aard van die Godsbemoeienis word sigbaar in onder andere:

* $\quad 100 \%$ Goddelike uitverkiesing en 100\% menslike verantwoordelikheid.

- Die Bybel 'n 100\% Goddelike en 100\% menslike boek.

Hierdie tweeslagtige wonderkarakter van die Godsbemoeienis kan teruggevoer word tot die onverstaanbare wonder van Jesus Christus wat $100 \%$ mens geword het, en tog $100 \%$ God gebly het. Slegs vanuit hierdie genadige wonder word alle ander Godsbemoeienis moontlik.

Die erkenning van die wonderkarakter van die Godsbemoeienis, ook in die teologie, hef nie die wetenskaplike en kritiese aard van die teologie as wetenskap op nie. Dit hef egter wel die moontlikheid op om alles rasioneel deursigtig te maak. By laasgenoemde (onmoontlike) ideaal loop die 'nuwere' herneneutiek se Kritiese Rasionalisme waarskynlik op die rotse.

Daar bestaan egter ook ' $n$ ander gevaar vir die teoloog - ' $n$ gevaar wat Snyman in sy artikels belig. Waar die 'nuwere' hermeneutiek die wonderkarakter van die Godsbemoeienis in die teologie onderspan, kan dit ook maklik oorspan word. Wanneer ' $n$ Gereformeerde teoloog in die lig van die wonderkarakter van die Godsbemoeienis, in die teologie 'n slegs meganiese (Snyman, 1992a:253) rol aan homself sou toeken, wanneer hy meen dat hy sy sondige gebrokenheid kan ontvlug deur die Bybel objektief te sou kon lees (Snyman, 1992a:257,258), en wan-

17 Die moontlikheid om wetenskaplik oor voorwetenskaplike vrae tc handel word tereg reeds deur Van Wyk $(1983: 214,215)$ bevraagteken Volgens hom sou dit uttloop op 'n deurvra sonder einde. 
neer hy meen dat die kommunikasie tussen God en mens, van die mens se kant af beskou, probleemloos is (Snyman, 1992a:259), sou hy inderdaad die wonderkarakter van die Godsbemoeienis skeeftrek, en daardeur ' $n$ onhoudbare teologie beoefen.

Die Gerefonmeerde teologie moet homself ten opsigte van hierdie aanklagte krities ondersoek - nie in die eerste plek ondat so 'n benadering Platonisties, positivisties en naïef-realisties sou wees nie, maar omdat dit nie erns met die Godgeopenbaarde werklikheid van die sondige gebrokenheid van die mens maak nie. Alhoewel die mens in hierdie benadering op die oog af opsygeskuif word (Snyman, 1992a:256), lê 'n ongeoorloofde verheerliking van die mens eintlik daaragter.

Die Gereformeerde teologie moet streef na 'n volmaakte balans in die erkenning van die wonderkarakter van die Godsbemoeienis. Die beslaglegging deur die werklikheid van Jesus Christus moet $100 \%$ gehandhaaf word én die wetenskaplike verantwoordelikheid van die teoloog moet $100 \%$ gehandhaaf word.

Het die Gereformeerde teologie binne hierdie beskouing dan hoegenaamd 'n kritiese en probleemoplossende vermoë? 'n Gekwalifiseerde ja kan die antwoord wees. Gekwalifiseerd ja, omdat die belydenis van die gebrokenheid van die mens noodwendig lei tot die erkenning van die onmoontlikheid om die Skrif volmaak te verstaan, en die erkenning van die voorlopigheid van teologiese teorieë en standpunte. 18

Hierdie belydenis verander egter niks aan die roeping van die teoloog om met alle gawes tot sy beskikking na volınakkte interpretasie te streef asof dit moontlik is nie: Christus lê immers beslag op elke konteks. Die mikpunt van die interpretasie is die konkretisering van die werklikheid van Christus in 'n bepaalde konteks. Die taak van die hermeneutiek sou beskryf kon word as die sigbaarmaking van hierdie beslaglegging vanuit die Woord.

So 'n gekwalifiseerde kritiese en probleemoplossende ingesteldheid vind in die eerste plek gestalte in die Gereformeerde teoloog se persoonlike geloofslewe: 'n voortdurende ondersoek van sy eie lewe in elke konteks om vas te stel of dit die oorwinning van Christus oor die sondige gebrokenheid vergestalt, moet plaasvind. Hiervandaan gaan (bewustelik en onbewustelik) 'n bepalende invloed op die teoloog se vooronderstellings uit.

18 In hierdie verband kan die baic belangrike voorstelle van Botha (1986 279-283) in Koers moer aandag geniet 
Tweedens moet hierdie ingesteldheid neerslag vind in die voortdurende toetsing van teologiese teorieè en standpunte. Hierdie toetsing vind onder begeleiding plaas:

* Begeleiding van die Heilige Gees (gebed, eksegese, Skrif-met-Skrif-vergelyking).

* Begeleiding van gelowige eksegese deur die eeue (belydenis, sinodebesluite, navorsingsresultate).

* Begeleiding van die Gereformeerde akademiese gemeenskap (studieleiers, promotors, kollegas).

Derdens moet hierdie ingestelheid lei tot ' $n$ bereidheid om te kommunikeer en te debatteer - ' $n$ bereidheid en gereedheid om te antwoord en te verantwoord (Kol. $4: 5,6)$.

\subsection{Ontwerpende en progressiewe aard}

Waar daar in die Gereformeerde teologie in sommige gevalle waarskynlik te min rekening gehou word met die teoriebepaaldheid en voorlopige aard van teologiese standpunte, loop die benadering van die Kritiese Rasionalisme skipbreuk teen relativisme.

Om werklik ontwerpend en progressief van aard te wees, sal 'n teologie albei hierdie slagysters moet vermy.

Die uiteindelike beskouing oor wat progressief in die teologie is, sal sy vertrekpunt moet neem in die gelowige aanvaarding van die feit dat God se werk voortgaan, ondanks die mens. ${ }^{19}$ Terselfdertyd gaan hierdie werk egter, deur die genadige beskikking van God, ook voort deur die mens.

Die Gereformeerde teoloog moet dus nie mislei word om onverskillig te staan teenoor die verantwoording van standpunte en teorieë, of die oorweging van metodes wat uit nieteologiese en nie-Gereformeerde bronne afkomstig is nie. $\mathrm{Al}$ is die progressie van die teologie 'n saak wat $100 \%$ in God se hande is, en wat deurgaan ongeag die mens, is dit ook terselfdertyd, wonderbaarlik onverstaanbaar $100 \%$ die verantwoordelikheid van die teoloog. Daarom moet hy met alle vermoëns en alle geweegde middele en metodes tot sy beskikking, homself $100 \%$

'n Oorsig van dic geskicdenis van dic tcologie sou kon aantoon dat kenteoreticse suiwerheid en wetenskaplikheid nic altyd 'n voorwaarde vir progressie was nie Metodes wat vandag as onhoudbaar beskou word, is in die verlede met vrug gebruik om dic werklikheid van Jesus Christus in 'n bepaalde konteks sigbaar te maak. Net so sal hedendaagse bruikbare metodes waarskynlik in dic tockoms aanvegbaar wees 
gee om onder begeleiding gelowig-wetenskaplik, verantwoordelik en ontwerpend besig te wees met die teologie in sy taak tot konkretisering van die werklikheid van Christus in elke konteks.

Wie dus werklik aktief betrokke wil wees by progressie in die teologie, moet homself uitlewer aan die paradoksale karakter van die Godsbemoeienis. Nederig, maar tog ook gelowig-vertrouend kan die teoloog dan voortgaan met sy taak om aan te toon hoe Christus alles en in almal is (Kol. 3:11).

\section{Slot}

Bied die paradigma waarin Snyman teologie wil beoefen beter brood en klere? Hierdie vraag word met ' $n$ versigtige nee beantwoord. Dit wil voorkom of die Kritiese Rasionalisme inderdaad uit die oog verloor dat dit in die teologie uiteindelik gaan om mense wat tot eer van God geestelik gevoed en geklee moet word.

Terselfdertyd bied Snyman se indringende kritiek 'n waardevolle bydrae om bepaalde aspekte van die Gereformeerde teologiese produksielyn volgens die voorwaardes van 'n 'eie paradigma' in heroorweging te neem en te moderniseer.

Sodoende lewer sy artikel tog 'n groot bydrae tot beter brood en klere.

\section{Bibliografie}

ALBERT, H 1968 Traktat über kritische Vernunft Tübingen : Mohr

BARTLEY, W W 1964 The Retreat to Commitment London: Chatto \& Windus

BOTHA, J. 1986. Die Gereformeerde Skrifbeskouing en moderne metodes van verklaring van die Nuwe Testament Koers, 5l(3) 259-286.

BOTHA, J. 1989 Semeion Inleiding tot die interpretasie van die Griekse Nuwe Testament Potchefstroom : PU vir $\mathrm{CHO}$

COETZEE, C.F.C. 1988. Die interpretasie van belydenis. (In De Bruyn, P J red. Waar die paaie saamwoon. Huldigingsbundel opgedra aan prof $\mathrm{PW}$ Buys Potchefstroom Potchefstroom Teologiese Publikasies p 25-36)

COETZEE, J.C. 1979. 'n Ou Boek in 'n nuwe wêreld, of 'n nuwe Boek in 'n ou wêreld? In die Skriflig, 13(49):4-15

DEIST, F.E. 1984 'n Kritiese evaluering van die kritiek van F N. Lion-Cachet In die Skriflig, 18(72):47-56.

DEIST, FE. 1986. Kan ons die Bybel dan nog glo? Onderweg na 'n gereformeerde Skrifbeskouing. Pretoria : Van Schaik

DEIST, F.E 1991. Objektiewe Skrifuitleg? Kanttekeninge by Skrifuitleg in die Ned Geref Kerk 1930-1990. Hervormde Teologiese Studies, 47(2):367-385

FLOOR L. 1979. Hoe gebruik die teoloog die Skrif? Koers, 44(1) 8-17.

GEERTSEMA, H G 1969. Enkele opmerkingen in verband met Hermeneutiek Bullerin, 20 $31-42$

HEMPELMANN, H. 1980. Kritischer Rationalismus und Theologie als Wissenschaft Wuppertal : Brockhaus 
JANSE VAN RENSBURG, F. 1991. Tendense in Nuwe Testament-literatuur-navorsing. In die Skriflig, 25(4):531-551.

KUHN, T.S. 1970. The Structure of Scientific Revolutions. Chicago : University of Chicago.

LATEGAN, B C 1984. Current Issues in the Hermeneutical Debate. Neofesiamentica, $18: 1-17$.

LION-CACHET, F N. 1984. 'n Kritiese beskouing van Deist se "ABC van Bybeluitleg". In die Skriflig, 18(69):38-51

LION-CACHET, F.N. 1985. Antwoord op Deist se kritiek In die Skriflig, 19(75) 45-48.

MOUTON, J., VAN AARDE, A.G. \& VORSTER, W.S. eds. 1988 Paradigms and Progress in Theology. Pretoria : RGN

OUWENEEL, W.J. 1991. Korrespondensie of koherensie. Koers, 56(2):167-184

PANNENBERG, W. 1973. Wissenschaftstheorie und Theologie. Frankfurt am Main : Suhrkamp.

SAUTER, G. 1975. Grundzüge einer Wissenschaftstheorie der Theologie Wissenschaftstheoretische Kritik der Theologie Munchen : Chr. Kaiser.

SNYMAN, G. 1992a. Kenteoretiese besinning oor teologiebeoefening aan die Teologiese Skool van Potchefstroom die afgelope twintig jaar. In die Skriflig, 26(2):247-266.

SNYMAN. G. 1992b Binnegevegte in die GKSA: verskuiwing van "plausibility structures"? In die Skriflig, 26(3):351-367

SNYMAN, J.J. 1991 Doppers se dilemma "Stem van Potch" is stil. Insig: 10-12, Mei

THOM, J.C. 1983. 'n Kritiese evaluering van dr. Fika van Rensburg se metode van sintaktiese struktuurontleding (In Van Rensburg, F. red Evaluering van prof. Fika van Rensburg se metode van sintaktiese struktuurontleding deur Suid-Afrikaanse Nuwe-Testamentici. Diktaat S216/83. Potchefstroom : Dept Sentrale Publikasies. p 1-4)

VAN AARDE, A G 1988. Historical Critisism and Holism Heading towards a New Paradigm? (In Mouton, J., Van Aarde, A.G \& Vorster, W.S eds Paradigms and Progress in Theology Pretoria : RGN. p. 49-64.)

VAN HUYSSTEEN, W. 1983. Rasionaliteit en kreatiwiteit Ontwerp vir 'n kritiese, konstruktiewe teologie. Koers, 48(3):185-213

VAN HUYSSTEEN, W. 1987. Teologie as kritiese geloofsverantwoording Teorievorming in die sistematiese teologie Pretoria : RGN.

VAN WYK, J.H. 1983. Responsie op lesing van prof Wentzel van Huyssteen. Koers, 48(3) 214-220

VAN WYK, J H 1985. Skrifgesag, teologie en kerk In die Skriflig, 19(2):42,43 